\title{
Financial and trade relationships between the Eurozone and China in the age of resilience
}

\author{
Alessandro Del Ponte ${ }^{1} \cdot$ Paolo Canofari $^{2} \cdot$ Audrey De Dominicis $^{3}$
}

Received: 6 May 2020 / Revised: 5 February 2021 / Accepted: 13 May 2021 /

Published online: 3 June 2021

(c) The Author(s), under exclusive licence to Springer-Verlag GmbH Germany, part of Springer Nature 2021

\begin{abstract}
How did the financial and trade ties between China and the Eurozone develop in the aftermath of the Eurozone sovereign debt crisis? We analyze these trends until the start of the COVID-19 pandemic. Using data from the Bank of International Settlements (BIS) and the International Monetary Fund (IMF), we examine the financial and trade dynamics between the two currency areas and analyze the related risks and opportunities. The data point to several patterns. We find that financial volatility in China has been substantially greater than in the Eurozone. Even so, the largest and strongest Eurozone economies-France and Germany-have largely kept their investments in Chinese assets after a four- to sixfold expansion that started in the mid-2000s. In contrast, the financially weakest countries have accounted for the largest increases in trade volumes between China and the Eurozone. We also find that trade volumes are correlated with holdings of Chinese financial assets but assets rose at a substantially smaller rate than trade. These results show that China and the Eurozone continue to be asymmetrically integrated, whereby Eurozone countries still invest more timidly in Chinese financial assets compared to the aggressive trade and infrastructure partnerships initiated by China. We discuss the implications for future financial and trade integration between the two currency areas, which is bound to deepen in light of the Comprehensive Agreement on Investment.
\end{abstract}

JEL classifications: F0 - International Economic Order and Integration · F14 Empirical Studies of Trade · G21 - Banks · H63 - Sovereign Debt

How did the financial and trade integration between China and the Eurozone develop in the aftermath of the Eurozone sovereign debt crisis, and how has it been affected by the financial fragilities of the two currency areas? In this paper, we attempt an answer to these questions, adding to the small but growing literature on the financial

Alessandro Del Ponte

alessandro.delponte@nus.edu.sg

Extended author information available on the last page of the article 
and trade interlinkages between the Eurozone and China (Christiansen and Maher 2017; Langhammer and Schweickert 2006; Meunier, Burgoon, and Jacoby 2014; Plummer 2006; Pomfret 2014).

Amid the deadliest pandemic since the Spanish flu of 1918-1920, the world has been as alert as ever to financial and commercial interconnectedness as countries are increasingly tempted to choose autarky as a response to the spread of the COVID-19 disease. While it is too early to gauge how lasting the effects of the pandemic will be on global finance and trade, we can examine their trends up until the current global crisis. In this paper, we focus on the financial and trade relationships between the Eurozone and China, two currency areas that have grown more integrated since the 2000s but especially since the aftermath of the sovereign debt crisis in the Eurozone. We assess the economic and financial fragilities in both currency areas, how they may have affected recent relationships, and discuss how they may shape future strategies.

This article unfolds as follows: First, we assess the financial fragilities in China and the Eurozone since its inception, with a special focus on the aftermath of the Eurozone crisis. Then, we study the volumes of financial investments in Chinese assets by Eurozone countries. In addition, we examine the trade relationships between the two areas and test whether a relationship exists between the acquisition of Chinese financial assets and trade volumes. We conclude by discussing the implications for the financial and trade integration between China and the Eurozone.

\section{Financial fragilities in China and the Eurozone}

The Chinese financial system has grown very rapidly since the early 1990s, with growth rates never below 6\% even during the Great Recession of 2008, and plays now an important role in the international financial system (Min et al 2018). After joining the World Trade Organization (WTO), the Chinese capital account has been characterized by large capital inflows. Yet, in 2014, the country suffered a capital flight that worsened after the renminbi (RMB) depreciation of 2015 (Allen, Qian, and Gu 2017; Chan 2017). The Chinese interbank market may also represent a source of fragility and potential contagion to Europe in the event of a banking crisis because of its rapid growth (Allen et al. 2012). Moreover, the risk of a bursting bubble in the Chinese economy may be worsened by significant capital outflows (Caballero and Krishnamurthy 2006), which may speed up in the aftermath of the COVID-19 crisis.

To examine the main risk factors and the financial interlinkages between China and the Eurozone, we use data from the Bank of International Settlements (BIS Statistics Explorer 2021) consolidated banking statistics and International Monetary Fund (2021) data. BIS Consolidated Banking Statistics provide a very useful tool for assessing the country-specific risks of the main banks reporting to BIS. Unfortunately, however, Chinese banks do not report their exposure to other countries to BIS.

A major factor to assess financial risk is represented by the credit-to-GDP gap, which is obtained by the difference between the short-run value of the creditto-GDP ratio (expressed as $\frac{\text { Nominal debt of the private non-financial sector }}{\text { Gross Domestic Product }}$ ) and its long-run 


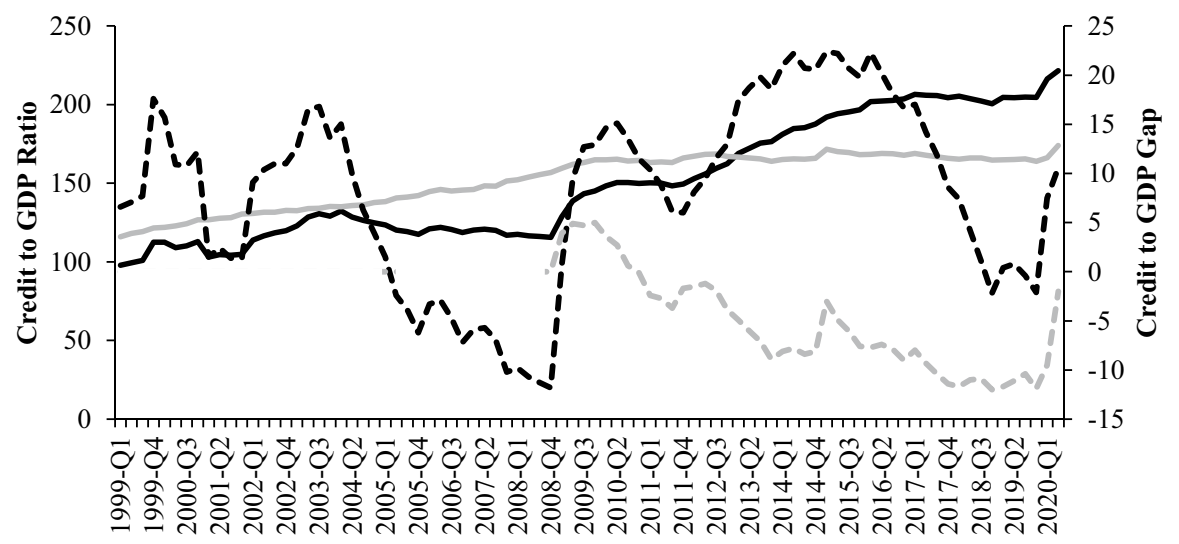

China Credit/GDP Ratio (left axis)
- - China Credit/GDP Gap

Euro area Credit/GDP Ratio (left axis)

- Euro area Credit/GDP Gap

Fig. 1 Credit to GDP ratio and credit to GDP ratio in China and the Eurozone 1999-2020. Note. Credit to GDP ratios (solid lines) is indexed on the left axis; Credit to GDP gaps (dashed lines) is indexed on the right axis. Authors' elaboration of BIS data

trend. The credit-to-GDP gap is widely recognized as a leading indicator of financial crises (see, e.g., Drehmann, Borio, and Tsatsaronis 2011), especially if proper time-series techniques and long time series are available. It is considered a better indicator than the credit-to-GDP ratio because it corrects for the sustainability of the debt instead of considering the overall amount.

Looking at several major crises over the past decades, the Basel Committee on Bank Supervision (BCBS) found that in many instances, the credit-to-GDP gap was greater than $8 \%$ before the inception of a severe financial crisis. Figure 1 shows the credit-to-GDP gap and the credit-to-GDP ratio for China and the Eurozone between 1999 and 2020. In the mid-2010s, China's credit-to-GDP gap was perilously above $20 \%$. As a result, China has been monitored for the worrisome dimensions of its financial leverage. After the gap closed in 2018-2019, it quickly rose to $10 \%$ in Q2 of 2020, confirming the volatile trend in the first two decades of the century. A look at the time series for the credit-to-GDP gap (black dashed line) past 2009 reveals that the gap exhibited a variance of 53, suggesting the absence of long-term stability. If we consider the full time series, the variance is 86. Moreover, the time series displaying the credit to GDP ratio (left y-axis, black solid line, Fig. 1) reveals that the ratio doubled in two decades, reaching $200 \%$. Thus, the Chinese financial system remains vulnerable to slipping again into high-risk territory.

In contrast to China, the Eurozone has been remarkably more stable since its inception in 1999. Since 2009, when the time series for the credit gap becomes available (gray dashed line), the credit gap's variance of 26 in the Eurozone was half of China's over the same period. Also, the credit to GDP ratio grew just a little over $40 \%$ in 20 years (gray solid line). Figure 1 shows that compared to the Eurozone, China has been bearing substantially more financial risk. 
Table 1 Chinese financial assets (billions of USD) by holding country in the period 2000-2020

\begin{tabular}{|c|c|c|c|c|c|c|c|}
\hline Year & Austria & Belgium & France & Germany & Italy & Spain & Total \\
\hline 2000 & 0.99 & 0.74 & 7.71 & 7.26 & 0.94 & 0.68 & 18.32 \\
\hline 2001 & 0.39 & 0.81 & 5.91 & 6.94 & 0.84 & 0.55 & 15.44 \\
\hline 2002 & 0.29 & 0.97 & 5.27 & 7.22 & & 0.45 & 14.20 \\
\hline 2003 & 0.43 & 1.13 & 7.28 & 7.74 & & 0.38 & 16.96 \\
\hline 2004 & 0.51 & 1.93 & 8.20 & 8.38 & 0.66 & 0.32 & 20.00 \\
\hline 2005 & 0.50 & 1.56 & 8.14 & 9.76 & 0.80 & 0.23 & 20.99 \\
\hline 2006 & 0.88 & 2.36 & 9.42 & 12.80 & 0.85 & 0.26 & 26.57 \\
\hline 2007 & 1.49 & 5.71 & 18.24 & 19.10 & 2.02 & 1.50 & 48.06 \\
\hline 2008 & 1.71 & 6.68 & 19.48 & 18.66 & 2.28 & 2.35 & 51.16 \\
\hline 2009 & 1.89 & 3.51 & 15.84 & 16.05 & 2.41 & 3.28 & 42.98 \\
\hline 2010 & 2.17 & 1.41 & 20.25 & 18.52 & 3.61 & 6.36 & 52.32 \\
\hline 2011 & 2.97 & 1.21 & 31.24 & 26.35 & 5.42 & 8.88 & 76.07 \\
\hline 2012 & 2.25 & 1.16 & 28.97 & 23.85 & 3.70 & 8.51 & 68.44 \\
\hline 2013 & 2.73 & 1.45 & 39.67 & 29.46 & 5.61 & 8.79 & 87.71 \\
\hline 2014 & 2.66 & 2.24 & 56.57 & 40.25 & 7.99 & 8.35 & 118.06 \\
\hline 2015 & 1.66 & 1.51 & 44.60 & 32.01 & 4.00 & 5.75 & 89.53 \\
\hline 2016 & 0.86 & 1.04 & 42.34 & 26.37 & 4.13 & 4.25 & 78.99 \\
\hline 2017 & 1.08 & 1.17 & 55.07 & 28.60 & 5.71 & 4.56 & 96.19 \\
\hline 2018 & 1.20 & 1.24 & 51.65 & 29.98 & 3.48 & 6.87 & 94.42 \\
\hline 2019 & 1.09 & 1.29 & 41.38 & 25.22 & 3.57 & 5.84 & 78.39 \\
\hline 2020 & 0.97 & 1.24 & 45.40 & 19.19 & 4.40 & 5.85 & 77.05 \\
\hline Total & 28.82 & 40.36 & 562.63 & 413.71 & 62.42 & 84.01 & 1191.85 \\
\hline
\end{tabular}

Source: Authors' elaboration of Bank for International Settlements (2020) data. Data for Italy in 2002 and 2003 are not available

\section{Financial investments of Eurozone member states in China.}

Financial actors in the Eurozone have reacted to financial volatility in China by disinvesting from Chinese assets since the mid-2010s. Table 1 displays for the period 2000-2020 the Chinese financial assets (in billions of USD) in the hands of the Eurozone countries that hold the largest amount of assets. Among them, Germany and France stand out as the largest holders of Chinese financial assets due to their strong export relationship with China. Germany is by far the largest player in bilateral trade between the EU and China. For instance, in 2008, Germany accounted for $43 \%$ of EU exports to China (34 billion euros) and $21 \%$ of total imports from China (51 billion euros) (European Parliament 2011). Meanwhile, China is Germany's most important market for plant and machinery installers (Von Hein 2014). At the same time, France is the second European supplier for China, especially in the drinks, aeronautic, and pharmaceutical industry (Bortolini and Jacques 2019).

Looking at trends in the Eurozone over time, it is evident that starting from 2000, countries have substantially expanded their investment in Chinese financial assets, 
Fig. 2 Chinese assets held by the largest Eurozone countries, 2005-2020. Note. Source: Authors' elaboration of Bank for International Settlements (2020) data

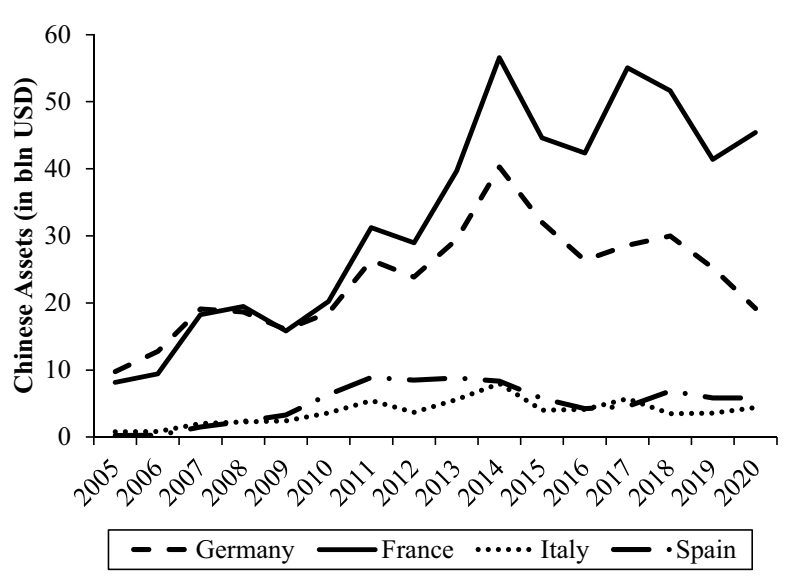

which grew up to $500 \%$ in a decade in Belgium. The largest Eurozone investors have increased their Chinese assets up to sixfold over 20 years, peaking at 118 billion dollars in 2014. But after the 2014 peak and a temporary trend reversal in 2017 and 2018, investments have been on the decline. This trend may be further exacerbated by the COVID-19 pandemic, which wreaked havoc in Eurozone countries.

We can better appreciate a snapshot of the trend of Eurozone investments in Chinese financial assets over time in Fig. 2, which covers the period 2005-2020. The figure focuses on the four largest economies in the Eurozone-France, Germany, Italy, and Spain. We can see that French, German, and Italian investments largely comoved whereas Spain followed a somewhat different pattern. We observe an increasing pattern up to 2014, specifically during the first two quarters for Italy and Spain, while for Germany and France, this increase occurs until the beginning of the last quarter. The sudden decrease that followed the long upward trend may be ascribed to a 3\% slowdown in the Chinese GDP growth rate that occurred in 2015. Then, they picked up in 2017 and dropped again in subsequent years. The drop has been particularly prolonged in Germany.

These investment dynamics were affected by the onset of the trade war between China and the USA, when on March 22, 2018, President Trump announced the imposition of about 50 billion dollars of customs duties on products from China. In French, Italian, and German markets, the reaction to this US decision also affected financial investments, causing volumes to drop from the second quarter, especially in France and Germany, while Italy continued with the slow decline already undertaken in the first quarter of 2018.

Next, we can look more specifically at the percentages of the various sectors that owned Chinese assets in 2020. We focus on nine major Eurozone countries and other key investors outside of the Eurozone (Table 2). These percentages reflect the contribution of the various sectors compared to the total assets of each country in our sample. The nine largest Eurozone investors account for nearly a fifth of the overall contribution of the main worldwide bank holders of Chinese assets. This figure is second only to US banks, which are the largest holders of Chinese assets. Several patterns emerge. Overall, Eurozone investors invest in 
Table 2 Main bank holders of Chinese assets by country. Data are broken down by counterparty sector

\begin{tabular}{|c|c|c|c|c|}
\hline & Total $\%$ & Banks \% & Official sector $\%$ & $\begin{array}{l}\text { Non-bank } \\
\text { private sec- } \\
\text { tor } \%\end{array}$ \\
\hline Austria & $0.31 \%$ & $1.00 \%$ & $0.02 \%$ & $0.01 \%$ \\
\hline Belgium & $0.18 \%$ & $0.37 \%$ & $0.01 \%$ & $0.12 \%$ \\
\hline Finland & $0.14 \%$ & $0.00 \%$ & $0.00 \%$ & $0.18 \%$ \\
\hline France & $7.42 \%$ & $9.51 \%$ & $5.39 \%$ & $6.09 \%$ \\
\hline Germany & $3.89 \%$ & $4.21 \%$ & $3.54 \%$ & $3.09 \%$ \\
\hline Ireland & $0.00 \%$ & $0.00 \%$ & $0.00 \%$ & $0.00 \%$ \\
\hline Italy & $0.86 \%$ & $1.50 \%$ & $0.66 \%$ & $0.48 \%$ \\
\hline Portugal & $0.05 \%$ & $0.00 \%$ & $0.00 \%$ & $0.06 \%$ \\
\hline Spain & $1.67 \%$ & $2.27 \%$ & $0.02 \%$ & $1.77 \%$ \\
\hline Australia & $3.96 \%$ & $2.37 \%$ & $6.85 \%$ & $3.12 \%$ \\
\hline Canada & $1.53 \%$ & $2.04 \%$ & $1.82 \%$ & $0.93 \%$ \\
\hline Chile & $0.01 \%$ & $0.01 \%$ & $0.00 \%$ & $14.30 \%$ \\
\hline Japan & $14.67 \%$ & $15.19 \%$ & $10.70 \%$ & $13.96 \%$ \\
\hline Korea & $4.01 \%$ & $4.14 \%$ & $1.56 \%$ & $4.10 \%$ \\
\hline Sweden & $0.46 \%$ & $0.65 \%$ & $0.15 \%$ & $0.42 \%$ \\
\hline Turkey & $0.00 \%$ & $0.00 \%$ & $0.00 \%$ & $0.00 \%$ \\
\hline Taiwan & $10.61 \%$ & $18.55 \%$ & $4.03 \%$ & $7.52 \%$ \\
\hline United Kingdom & $34.72 \%$ & $25.32 \%$ & $48.46 \%$ & $29.54 \%$ \\
\hline United States & $15.51 \%$ & $12.86 \%$ & $16.81 \%$ & $14.30 \%$ \\
\hline Total & $100 \%$ & $100 \%$ & $100 \%$ & $100 \%$ \\
\hline
\end{tabular}

Source: Authors' elaboration of Bank for International Settlements (2020) data

Chinese banks, but some member states, including Finland, France, Ireland, and Portugal, invest primarily in the non-bank private sector. Investments in the official sectors are generally smaller but extremely significant for Germany.

Looking at global comparisons, it is interesting to note that UK banks' investments in Chinese assets account alone for over two-thirds of holdings of Chinese assets in Europe. This figure reflects the fact that the UK is still the financial hub of Europe also in the post-Brexit world. Nonetheless, it is noteworthy that in addition to the countries geographically close to China and with a flourishing economic history, German and French banks are among the largest holders of Chinese assets, especially for the banking sector. This is interesting as the conventional wisdom suggests that cross-border equity flows largely depend on physical proximity between countries (Portes and Rey 2005). We can compare the German figures to those of countries outside the Eurozone that are geographically close to China. The investments of France and Germany combined are approximately equivalent to the amount invested by Japan, a country with close-knit ties to China despite the ongoing territorial disputes. 
We can attempt an answer to why holdings of Chinese financial assets have remained relatively high after the debt crisis. During the sovereign debt crisis, European authorities asked China to invest in government bonds to help bail out countries facing speculative attacks, but the Chinese contribution came mainly in the form of investment projects and assets in European infrastructure (Casarini 2012). This is consistent with the data we collected from Bloomberg, which classify the main holders of sovereign debt securities issued in the Eurozone. However, we have not been able to find any significant holders of European bonds who are residents of China.

Thus, here, we suggest that the Chinese and European financial systems are asymmetrically integrated. Chinese banks and sovereign wealth funds may not have purchased significant amounts of bonds issued by financial institutions and governments in Europe, but they have certainly chosen foreign direct investments (FDIs) in the key industrial sectors of Europe (Kamiński 2017; Meunier, Burgoon, and Jacoby 2014). Specifically, in 2010-2019, Chinese FDIs in the EU totaled 157.6 billion Euros, $55 \%$ of which consisted of state-owned investments. Contrast this with 140 billion Euros invested by EU countries in China in over twice the time (2000-2019). FDIs likely paved the way for an increase in trade, as it typically occurs (Aizenman and Noy 2006). On the other hand, European countries have invested mostly in bonds issued by the Chinese government, by Chinese banks, and other financial companies.

\section{China-Eurozone trade dynamics}

After assessing the interdependencies between China and the Eurozone in terms of financial assets, we take a closer look at China's trade dynamics with the Eurozone. It is important to look at trade volumes especially in light of the side effects of the decisions implemented by the US government during the Trump presidency, which marked the escalation of an ongoing trade war between the USA and China.

Previous research has examined the flourishing trade dynamics between China and the Eurozone, emphasizing the clear benefits of these interlinkages but also warning for the potential political consequences for Europe (Geeraerts 2019; Menegazzi 2017; Meunier 2014). Despite the political concerns of undue Chinese influence in Europe, European countries have enthusiastically embraced the new Belt and Road Initiative launched by China. Remarkably, China was able to keep European interests split similar to previous occasions (Bungenberg and Hazarika 2017) and to close individual deals with each Eurozone country, thus avoiding a group negotiation with the largest economic bloc in the world. This strategic initiative of economic statecraft (Reilly 2017) has two main aims. On the one hand, to ensure support for China's leadership policies in trade with Europe; On the other hand, to stimulate investment opportunities and prospects for development for cash-strapped countries in the aftermath of the sovereign debt crisis (Pardo 2018). In this section, we scrutinize the trade dynamics between China and the Eurozone.

Do trade volumes reflect the investments in Chinese financial assets by major Eurozone countries? Before we answer this question, we look at trade dynamics 
Table 3 Trade volumes with China by Eurozone country (USD billions)

\begin{tabular}{lrrrrrrrl}
\hline & \multicolumn{1}{l}{2014} & \multicolumn{1}{l}{2015} & \multicolumn{1}{l}{2016} & \multicolumn{1}{l}{2017} & \multicolumn{1}{l}{2018} & \multicolumn{1}{l}{2019} & Total & Cumulative growth \\
\hline Austria & 8.253 & 7.464 & 7.250 & 8.384 & 9.757 & 10.645 & 51.753 & $28.98 \%$ \\
Belgium & 27.278 & 23.253 & 21.854 & 23.438 & 24.159 & 25.112 & 145.094 & $-7.94 \%$ \\
France & 56.091 & 52.023 & 48.003 & 55.423 & 63.535 & 65.685 & 340.760 & $17.10 \%$ \\
Germany & 177.507 & 156.674 & 152.421 & 168.409 & 184.368 & 184.743 & 1024.123 & $4.08 \%$ \\
Greece & 4.532 & 3.951 & 4.581 & 5.245 & 7.138 & 8.466 & 33.913 & $86.83 \%$ \\
Ireland & 6.535 & 7.110 & 8.092 & 11.061 & 14.521 & 16.717 & 64.036 & $155.80 \%$ \\
Italy & 48.032 & 44.634 & 43.303 & 49.697 & 54.496 & 54.832 & 294.994 & $14.16 \%$ \\
Portugal & 4.802 & 4.371 & 5.621 & 5.618 & 6.033 & 6.643 & 33.088 & $38.34 \%$ \\
Spain & 27.738 & 27.517 & 27.900 & 31.118 & 33.939 & 35.435 & 183.648 & $27.75 \%$ \\
Total & 360.769 & 326.996 & 319.024 & 358.393 & 397.947 & 408.279 & 2171.409 & \\
\hline
\end{tabular}

Source: Authors' elaboration International Monetary Fund (IMF) data

between the two currency areas. Table 3 shows the trade volumes with China of some countries. We find that between 2014 and 2019, trade volumes with China increased in all major Eurozone countries but Belgium $(-8 \%$, but with a growing trend since 2017). Across countries, volumes grew by $41 \%$ on average (Ireland stands out with a $156 \%$ increase in volumes). Overall, volumes grew by $13 \%$ in 6 years.

Some interesting patterns emerge. Most striking, trade volumes between the hardest-hit countries during the sovereign debt crisis increased substantially more than core Eurozone countries. To put numbers in perspective, trade volumes in Greece grew by $87 \%$ and in Ireland, they more than doubled $(+156 \%)$, whereas Portugal and Spain reported a $38 \%$ and $28 \%$ jump in volumes, respectively. Contrast this with a scant $4 \%$ increase in Germany and 17\% increase in France, in the Eurozone core. As noted by previous research (De Ville and Vermeiren 2016), the abrupt jump in trade volumes and, especially, in foreign direct investments (FDIs) in peripheral countries of the Eurozone may come at a political price and weaken the balance of payment situation of these already frail economies. However, this expansion seems to bring sufficient benefits to both sides of the relationship and it appears bound to continue.

Another trend is that trade volumes dropped post-2014 but rebounded starting in 2017. This pattern seems to mirror the numbers depicted in Fig. 2 concerning Chinese financial assets held by the largest Eurozone countries. Thus, we may expect the two trends to go hand in hand and form a stable relationship (more on this later).

Looking at trade volumes with peripheral Eurozone countries, it appears that China adopted a foot-in-the-door trade strategy in Europe. China entered more forcefully those markets that were left more vulnerable after the sovereign debt crisis, either in the form of imports or exports. As noted earlier, the surge in Chinese trade volumes with the affected countries likely filled a void left by the scars of the Eurozone crisis. Filling this void allowed China to gain a permanent foothold in the Eurozone and to consolidate its presence in the currency area. After the positive 
Fig. 3 China's main import partners in 2019, by the value of imports (in billion yuan). Note. Source: Authors' elaboration of International Monetary Fund (IMF) data

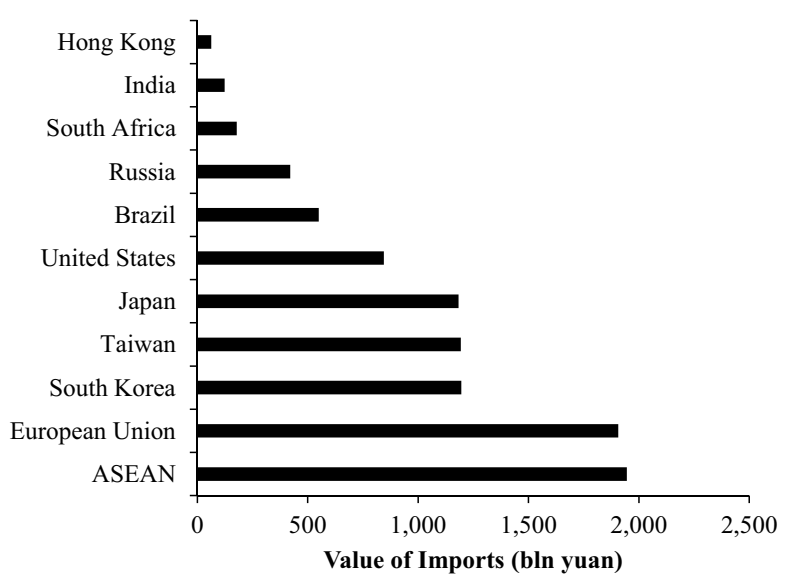

experience with closer commercial relations in the aftermath of the crisis, the Belt and Road initiative will likely consolidate the ties between the two currency areas and expand volumes further.

Trade volumes between China and the Eurozone deserve closer scrutiny. Thus, next, we look at Chinese imports from the Eurozone and we compare them to the figures of China's other key import partners in 2019 (Fig. 3). The most important Chinese import partners are Hong Kong, India, South Africa, Russia, Brazil, the USA, Taiwan, Japan, South Korea, ASEAN (Association of Southeast Asian Nations, which include China's key partners such as Thailand, Singapore, and Vietnam), and the European Union, which is largely comprised by Eurozone members.

Remarkably, in 2019, imports from the EU were almost on par with those from the ASEAN bloc, which is China's largest import partner in the region. To put the crucial importance of imports from Europe in perspective, EU imports were larger than imports from Brazil, Russia, India, and Hong Kong combined, and more than double the imports from the USA.

The importance of the Eurozone as China's main import partner underlies a growing trend in China's imports. Figure 4 shows the trend of the budget balance to GDP ratio for China starting from 2012 and displays forecasts until 2025 according to the IMF. In 2012, the ratio was slightly negative but close to balanced. However, during the 2010s, the ratio dropped substantially, reaching a nadir of $-6 \%$ in 2019 , which followed a $10 \%$ growth of Chinese total trade from 1848 to 2056 billion USD between 2014 and 2018.

Yet, after the global slowdown provoked by the COVID-19 pandemic, it will be very interesting to compare the forecasted data for 2020 and subsequent years with the actual data. At the time of writing, China seems to be past the peak of the crisis in the first two quarters of 2020, concluding the year with $2.3 \%$ GDP growth. This was the lowest growth rate in China since 1990, when the economy grew by $3.9 \%$. During the widespread lockdowns of the first quarter of 2020, entire sectors of the economy (including tourism, transportation, the food and beverage industry, 
Fig. 4 Budget balance in China relative to the gross domestic product (GDP) 2012-2025. Note. Authors' elaboration of IMF data. An asterisk* indicates a forecast released in October 2020

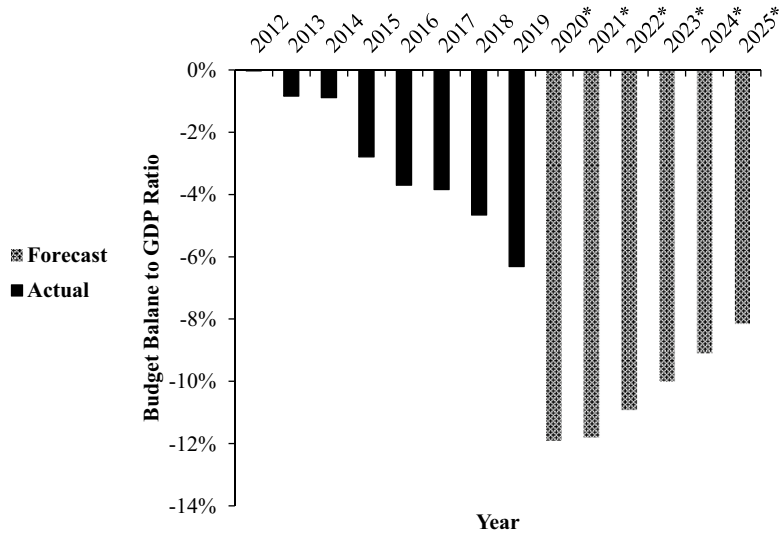

and even factories) plummeted due to widespread city lockdowns and a dropping demand. The forecasts incorporate expectations that the global spread of COVID-19 will continue to create disruptions in the global supply chain as well as a dropping demand in OECD countries.

More generally, in light of the COVID-19 pandemic, the drop in Chinese production and demand will likely reduce the trade volume between China and the rest of the world, including the Eurozone, which has been an epicenter of the global public health crisis. An important question is to what extent the COVID-19 pandemic will impact trade volumes, the volume of Chinese assets held by foreign banks, and Chinese assets' value.

China's increasingly negative budget balance to GDP ratio inevitably reflects in the growing national debt. Figure 5 displays the Chinese trend in the debt/GDP ratio since 2012 and extends the forecast until 2024, according to IMF estimates. China's debt/GDP ratio was just over 30\% in 2012 and nearly doubled by the end of the decade. The estimates indicate that the ratio will steadily increase in the years ahead.

Fig. 5 National debt of China relative to the gross domestic product (GDP), 2012-2025.

Note. Authors' elaboration of IMF data. An asterisk * indicates a forecast made in October 2020

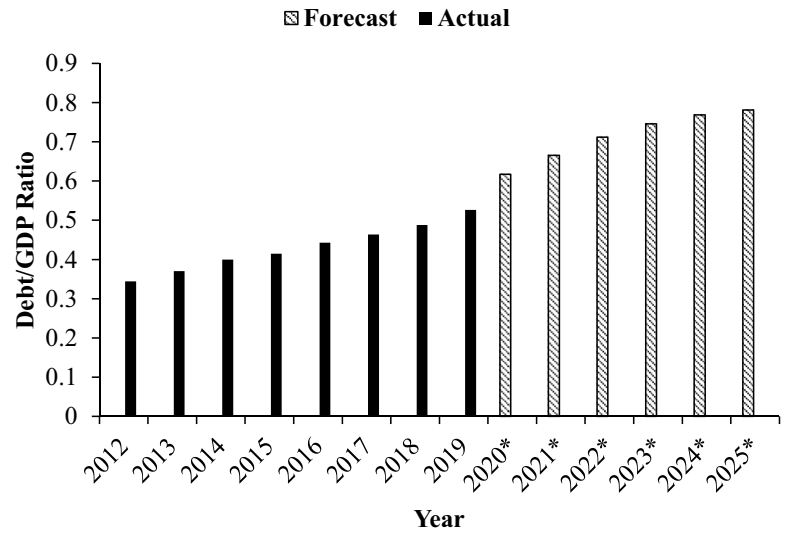


Fig. 6 Chinese investments 2005-2019 by global region. Note. The figure for North America excludes the USA, which is considered separately. Source: Authors' elaboration of IMF data

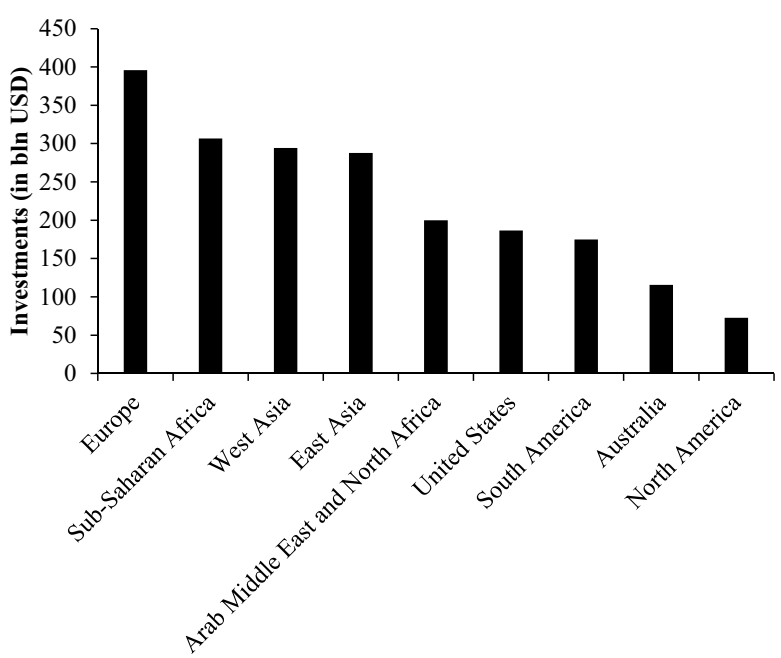

However, sovereign debt will remain at comparatively low levels if benchmarked against those of Eurozone countries. The Eurozone average was $85.9 \%$ in 2019, with Estonia leading the group with just $8.1 \%$ debt/GDP ratio and Greece with the highest ratio at $181.9 \%$. Hard-hit countries during the sovereign debt crisis still have not absorbed the legacy of exploding deficits, with Italy at $134 \%$, Portugal at $123 \%$, Belgium at $105.1 \%$, and France hitting the $100 \%$ mark. The largest economies in the Eurozone do not meet the standard of $60 \%$ debt/GDP ratio, and even Germany, with $61 \%$, is just shy of the target imposed by the Maastricht treaty in 1992. In light of the COVID-19 pandemic, sovereign debts soared in 2020 amid national budgets ravaged by falling tax proceeds and increased spending for healthcare, unemployment benefits, and support for businesses. The pandemic will hamper the already fragile sustainability of government debt in several Eurozone countries. Specifically, forecasts made in April 2020 (Kraemer 2020) projected Italy's debt/GDP ratio to balloon to $167 \%$ by 2022 (France, 135\%; Portugal, $144 \%$; Spain, 125\%).

Finally, after looking at the trade dynamics between China and the Eurozone and their effects on the balance of payment and sovereign debt, we now turn our attention to trends in investments by China around the world in the first two decades of the 2000s. We focus particularly on Europe and compare trends with other global regions. We do so as data about financial assets in the Eurozone held by China are unavailable. Figure 6 displays the aggregate Chinese investments between 2005 and 2019 by global region. We find that the volume of Chinese investments in Europe is substantially higher than investments in any other global region. With almost 400 billion USD, Chinese investments in Europe are even greater than investments in sub-Saharan Africa, which have soared since 2000 following China's strategic initiative to fund large-scale investments in countries that lack primary infrastructures, such as roads, bridges, and ports (Alves 2013; 
Campbell 2008; Sautman and Hairong 2007; Zafar 2007), but also in the natural resource sector (Kärkkäinen 2016). By comparison, China invested more in Europe than in all the NAFTA countries combined.

\section{The relationship between financial assets and trade volume}

The statistics presented so far about Chinese financial assets held by Eurozone banks and trade volumes between China and the Eurozone raise the question of whether there is a statistical relationship between financial assets and trade. Previous research suggests that volumes of trade and financial assets may be related. For instance, Aviat and Coeurdacier (2007) show that trading in goods increases trading in assets between countries by reducing information asymmetries. Moreover, employing a gravity model to estimate the influence of bilateral trade and trade openness on bilateral asset holdings, Peter (2012) found that bilateral and total trade flows boost bilateral asset holdings. Thus, using BIS data and IMF data, we next use a pooled OLS regression model to examine the relationship between the Chinese financial assets held by foreign countries and the trade volumes between these countries from 2014 to 2019.

Starting from the linear regression model:

$$
\begin{gathered}
Y_{i}=\beta_{0}+\beta_{1} X_{i}+\epsilon_{i} \\
\widehat{Y}_{i}=b_{0}+b_{1} X_{i}
\end{gathered}
$$

we calculate the regression line:

$$
\sum_{i=1}^{n}\left(Y_{i}-\widehat{Y}_{i}\right)^{2}
$$

Because of (2), we have:

$$
\sum_{i=1}^{n}\left(Y_{i}-\hat{Y}_{i}\right)^{2}=\sum_{i=1}^{n}\left[Y_{i}-\left(b_{0}+b_{1} X_{i}\right)\right]^{2}
$$

where $\mathrm{X}$ is the average level (in $\log$ ) of trade from 2014 to 2019 for all countries and $\mathrm{Y}$ is the average of assets (in log) from 2014 to 2019 for all countries.

Table 4 presents the regression results. In the three models, we consider first only Eurozone countries (column 1); then, in column 2, we use the full sample pruned from outliers (Japan, South Korea, Turkey, the UK, and the USA); finally, in column 3, we include the entire sample of 19 countries.

For all three models, the results reveal a positive and significant relationship between trade volume and assets. Specifically, we find that a $100 \%$ increase in trade volume corresponds to a $2 \%$ increase in the amount of Chinese financial assets held by Eurozone countries (column 1). This means that a $\$ 1$ bln increase in trade volume corresponds to a $\$ 202,000$ increase in 
Table 4 Linear regressions of Chinese financial assets held by foreign countries, 2014-2019

\begin{tabular}{llll}
\hline & $(1)$ & $(2)$ & $(3)$ \\
\hline & Coefficient & Coefficient & Coefficient \\
Constant & -8.63484 & -7.76676 & -7.54580 \\
Trade volume & $2.01793 * * *$ & $1.78943 * * *$ & $1.71926 * * *$ \\
$\mathrm{~N}$ & 9 & 14 & 19 \\
$\mathrm{R}^{2}$ & 0.70 & 0.45 & 0.253 \\
\hline$* * * p<0.01$ & & &
\end{tabular}

OLS regressions. The reference category is the trade volume and the Chinese assets held by a foreign country (in log). Column 1 includes only countries from the Eurozone (Austria, Belgium, France, Germany, Greece, Ireland, Italy, Portugal, and Spain); Column 2 adds Australia, Mexico, Panama, Sweden, and Switzerland; Column 3 includes the entire sample (including the outliers: Japan, Republic of Korea, Turkey, the UK, and the USA)

Chinese financial assets held. We obtain a similar figure for the regression that includes the full sample without outliers (column 2). The coefficient is somewhat smaller if we consider the entire sample of 19 countries where an increase of $1 \%$ in trade volume corresponds to an increase of $1.72 \%$ in Chinese financial assets. ${ }^{1}$

These results suggest that in the 2010s, global economies (particularly those in the Eurozone) have been hesitant to acquire Chinese financial assets compared to their involvement in trade with China. This hesitation may be explained not only by regulatory red tape but also by the fears over China's financial vulnerability, as we outlined above.

In Fig, 7, we focus exclusively on the relationship between assets and trade volume between the largest Eurozone holders of Chinese assets and China in 2014-2019. The figure does not include France and Germany as their Chinese financial assets are substantially greater than the rest of the Eurozone countries and thus are influential observations. We find again evidence of a more timid stance in acquiring assets than in engaging with trade. For comparison, in 2019, the global market capitalization was assessed to be 90 trillion USD whereby the global banking sector accounted for 7.9 trillion USD. In contrast, according to WTO data, global trade in merchandise and commercial services topped 25 trillion USD. Thus, we would expect higher volumes in financial assets than in trade. Yet, this is not what we find. Trade volumes are largely prevalent and exceed financial volumes by three orders of magnitude.

\footnotetext{
1 This model specification aims to provide suggestive evidence for the relationship between trade and Chinese financial assets held by foreign countries. This evidence is purely correlational and we leave more nuanced model specifications to future work.
} 


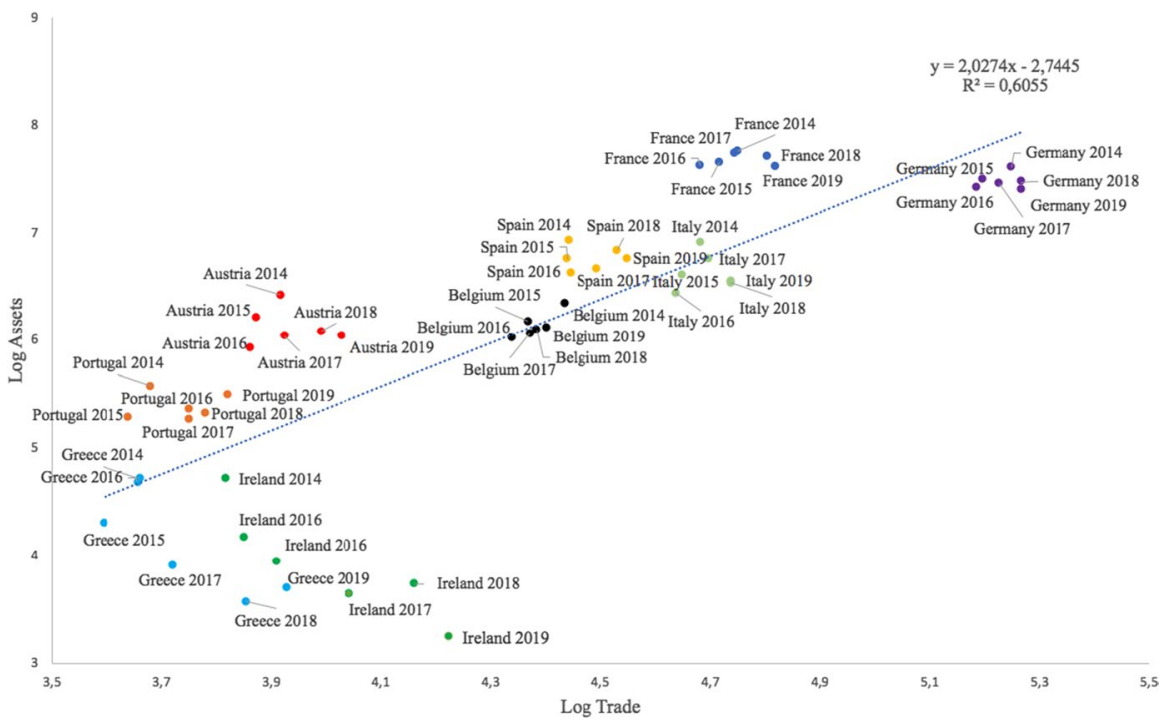

Fig. 7 Relationship between China-Eurozone trade volumes and Chinese financial assets held by major Eurozone countries (Austria, Belgium, Greece, Ireland, Italy, Portugal, Spain, France, and Germany) 2014-2019. Note. The x-axis represents the value of total Chinese assets held by Eurozone countries between 2014 and 2019; the y-axis represents the total trade of China with these countries. All axes are expressed in log. Source: Authors' elaboration of BIS data and IMF data

\section{Discussion and conclusions}

In this paper, we traced the developments of financial and trade ties between China and the Eurozone in the aftermath of the sovereign debt crisis in the Eurozone. Using BIS banking consolidated statistics and IMF data, we examined the strength of the financial and commercial ties between the Eurozone and China.

Despite the enormous expansion in volumes, the integration between the two currency areas still has vast untapped potential as it is largely asymmetric. A surge in Chinese trade and infrastructure investments in the Eurozone has involved-and benefited-mostly peripheral countries that were left impoverished and vulnerable by the sovereign debt crisis. In contrast, core Eurozone members such as France and Germany have experienced far smaller percentage increases between 2014 and 2019 (trade with Belgium even declined substantially). The financial relationships followed the opposite pattern. After a decade-long surge, financial investments in Chinese assets by Eurozone countries remained high only among core member states such as France and Germany whereas they stayed low among peripheral member states.

These diverging patterns underlie a distinct relationship between trade and financial volumes, however. In line with previous literature on international trade and finance (Aviat and Coeurdacier, 2007; Peter 2012), we find that trade and commerce volumes between China and the Eurozone have been positively correlated in the post-crisis period. Trade growth produced an equivalent growth in Chinese financial assets held by Eurozone banks that is smaller by several orders of magnitude. 
This finding suggests that financial actors in the Eurozone still consider the Chinese financial system too risky. Our analysis confirms this worry since the key indicator of financial risk - the credit-to-GDP gap — has been highly volatile in 2014-2020 and has reached alarming levels. In 2019, China managed to close the gap, but in 2020 , the gap was already soaring again past $10 \%$. If China can prove to financially be less volatile, Eurozone investors may flock back in. Previous work suggests that Chinese assets are still a residual fraction of the financial assets held by Eurozone banks. Moreover, since the debt crisis, the European Central Bank (ECB) has put in place appropriate firewall mechanisms that would be able to shield banks and governments if needed (Canofari and Del Ponte 2018).

The small financial volumes compared to the trade volumes and the total financial assets held by Eurozone banks suggests that there is significant room for further financial integration. This is valid both for core and peripheral countries but it may be especially useful information for investors in peripheral member states, where holdings of Chinese financial assets are still negligible. Even though shocks coming from within the Eurozone would hit mostly peripheral countries, the safeguard provisions by the ECB allay concerns over peripheral countries' banking system vulnerability to moderate-size shocks. Negative shocks coming from China would impact mostly core countries' banks since peripheral countries' banks do not possess a significant share of Chinese assets. Nonetheless, core countries' banks' exposure to a Chinese shock would likely be limited. This solidity would stem primarily from the relatively small size of Chinese assets held by the Eurozone banking sector compared to its overall dimensions but is also a consequence of the banking sector reforms that the Eurozone recently undertook, which improved the resilience of the system to future negative shocks. In short, the Eurozone financial system would likely prove robust to shocks coming from China.

During and after the COVID-19 crisis, banks in the Eurozone will be pressured to purchase government bonds of their own country. However, due to the asymmetric evolution of the pandemic, financial investments in Asia may provide excellent growth opportunities, as growth may restart first in Asia before Europe and the USA recover. Shifting the emphasis on financial assets in Asia may be a necessary move also due to the disruption of global supply chains.

Eurozone investors may be able to look at financial investments in China with greater confidence also by virtue of the better preparedness of the Eurozone itself in the face of external shocks on financial assets. It is important to emphasize that current firewall mechanisms and risk prevention procedures set by the ECB shield peripheral countries' banks particularly well (Blot et al. 2019). Previous research found that in the event of internal shocks and external shocks from China, vulnerabilities in the Eurozone are concentrated in core countries such as France and Germany (Canofari, Di Bartolomeo, and Messori 2017). However, despite even large losses on the assets that are most susceptible to negative shocks (i.e., Chinese assets and Eurozone peripheral government bonds), financial agents' losses would likely not be catastrophic. This is made possible by the stabilization mechanisms built into the ECB's shock-response function, which shields especially peripheral country banks, and the asset composition of the Eurozone financial sector at large, which appears sufficiently diversified to avoid pernicious consequences even in case of 
large negative shocks. Core countries' banks would likely be able to cope robustly with shocks even without specific ECB actions targeted at them.

As noted earlier, we found that the Eurozone is much more stable financially than China if we look at credit-to-GDP gaps. We posit that the stability of the Eurozone core stems from the reduced exposure that the financial sector in the core of the Eurozone underwent in the aftermath of the sovereign debt crisis. Balance sheet data suggest that if a new sovereign debt crisis was to unfold, it would hit the financial sector of peripheral countries the hardest, but the safety measures currently in place would protect them from another financial crisis. On the one hand, the unfolding of events in the early months of the COVID-19 crisis, which brought the surge of the spread between Italian BTPs and the German Bund and prompted a strong ECB response, reveals that peripheral Eurozone countries are most at risk. On the other hand, the ECB response-after the initial hesitation-shows that the Eurozone is well equipped to protect its weakest member states from tensions on the refinancing of their sovereign debt.

Also, during the COVID-19 crisis and its long aftermath, Eurozone countries will be in dire need to jump-start the economy and rebuild their healthcare infrastructure for future pandemic preparedness. Yet, most countries will not have sufficient financial resources to fund their projects, as tax proceeds plummeted due to the prolonged lockdowns and restrictions in key sectors of the economy. Thus, once again after the sovereign debt crisis, China seems uniquely well positioned to supply the needed FDIs to lead a Eurozone recovery, provided that geopolitical considerations allow for its involvement. As we saw after the sovereign debt crisis, FDIs would likely be accompanied by growth in trade and, to a lesser extent, financial relationships between the two currency areas. From a financial risk perspective, China and the Eurozone seem better equipped to undergo deeper integration than in 2015, especially after the EU-China Comprehensive Agreement on Investment (CAI) was reached in December 2020.

The CAI marks a historic milestone in the EU-China relationship and will be a key enabler to rebalance the financial and trade relations between the two areas toward greater and more symmetric integration. The CAI ensures better access for EU investors into China while preserving European control over strategic sectors in Europe such as energy and agriculture. The CAI is far-reaching in scope, as it ensures access to sectors such as manufacturing, automotive, financial and business services, healthcare, R\&D in biological resources, telecommunications (with a 50\% equity cap), computer services, maritime and air transport, environmental services, and construction services. Moreover, the CAI is equipped with a monitoring mechanism and a dispute settlement mechanism to ensure smooth functioning and safeguard the integrity of the accord.

A word of caution is warranted in drawing these conclusions because the COVID19 crisis poses an unprecedented threat to the global financial economy. Forecasts about future trends will likely have to be continuously readjusted as the crisis unfolds around the world. High uncertainty characterizes the COVID-19 era as globalization enters uncharted territory. While we cannot gaze into the future, we are convinced that analyzing pre-COVID-19 trends in finance and trade between the Eurozone and China can offer us greater insight into the complex relationship between the two 
currency areas and allow scholars and practitioners to better identify the opportunities offered by a greater integration between China and the Eurozone.

\section{References}

Aizenman J, Noy I (2006) FDI and trade-two-way linkages? Q Rev Econ Finance 46(3):317-337

Allen F, Qian JQ, Gu X (2017) An overview of China's financial system. Annu Rev Financ Econ 9:191-231

Allen F, Qian J, Zhang C, Zhao M (2012) China's financial system: Opportunities and challenges. In: Fan J, Morck R (Eds). Capitalizing China, University of Chicago Press

Alves AC (2013) China's 'win-win' cooperation: unpacking the impact of infrastructure-for-resources deals in Africa. South Afr J Int Affairs 20(2):207-226

Aviat A, Coeurdacier N (2007) The geography of trade in goods and asset holdings. J Int Econ 71(1):22-51

BIS Statistics Explorer (2021) Available via https://stats.bis.org/statx/toc/LBS.html

Blot C, Creel J, Hubert P, Labondance F (2019) The role of ECB monetary policy and financial stress on Eurozone sovereign yields. Empirical Econ, 59, 1-23

Bortolini C, Jacques E (2019) Les relations commerciales entre la France et la Chine en 2018 (douanes françaises). Direction general du trésor. Available at https://www.tresor.economie.gouv.fr/Articles/ 2019/04/04/les-relations-commerciales-entre-la-france-et-la-chine-en-2018-douanes-francaises. Accessed in January 2021.

Bungenberg M, Hazarika A (2017) The European Union's trade and investment policy in Asia: new challenges and opportunities in a changing global environment-or: following individual roadmaps. Asia Eur J 15(4):377-397

Caballero RJ, Krishnamurthy A (2006) Bubbles and capital flow volatility: causes and risk management. J Monet Econ 53(1):35-53

Campbell H (2008) China in Africa: challenging US global hegemony. Third World Q 29(1):89-105

Canofari P, del Ponte A (2018) Chinese and European financial systems: instability drivers and contagion channels. Int Adv Econ Res 24(4):311-324

Canofari P, Di Bartolomeo G, Messori M (2017) EMU stability: direct and indirect risk sharing. Open Econ Rev 28(5):847-862

Casarini N (2012) China's approach to US debt and the Eurozone crisis. LSE Ideas Special Report, June 2012: China's Geoeconomic Strategy, 43-47

Chan S (2017) Assessing China's recent capital outflows: policy challenges and implications. China Finan Econ Rev 5(1):3

Christiansen T, Maher R (2017) The rise of China-challenges and opportunities for the European Union. Asia Eur J 15:121-131

De Ville F, Vermeiren M (2016) The Eurozone crisis and the rise of China in the global monetary and trading system: the political economy of an asymmetric shock. Compar Eur Politics 14(5):572-603

Drehmann M, Borio CE, Tsatsaronis K (2011) Anchoring countercyclical capital buffers: the role of credit aggregates. Int J Cent Bank 7(4):189-240

European Parliament (2011) EU- China trade relations. Directorate-General for External Policies of the Union - Policy Department. Available online at: https:/www.europarl.europa.eu/RegData/etudes/ etudes/join/2011/433861/EXPO-INTA_ET(2011)433861_EN.pdf. Accessed in January 2021.

Geeraerts G (2019) The EU-China partnership: balancing between divergence and convergence. Asia Eur J 17(3):281-294

International Monetary Fund World Economic Outlook (2021) Databases available via https://www.imf. org/external/pubs/ft/weo/2019/02/weodata/index.aspx

Kamiński T (2017) Sovereign Wealth Fund investments in Europe as an instrument of Chinese energy policy. Energy Policy 101:733-739

Kärkkäinen A (2016) Does China have a geoeconomic strategy towards Zimbabwe? The case of the Zimbabwean natural resource sector. Asia Eur J 14(2):185-202

Kraemer M (2020) The eurozone is at risk of a debt crisis worse than the last one. Financial Times, April 10. https://www.ft.com/content/2289a1df-95b6-4cac-8854-04cdbe21c20c 
Langhammer RJ, Schweickert R (2006) EU integration and its implications for Asian economies: what we do and do not know. J Asian Econ 17(3):395-416

Menegazzi S (2017) Global economic governance between China and the EU: the case of the Asian infrastructure investment bank. Asia Eur J 15(2):229-242

Meunier S (2014) A Faustian bargain or just a good bargain? Chinese foreign direct investment and politics in Europe. Asia Eur J 12(1-2):143-158

Meunier S, Burgoon B, Jacoby W (2014) The politics of hosting Chinese investment in Europe-an introduction. Asia Eur J 12(1-2):109-126

Min Z, Weidong C, Jingtong Z, Xinzhe Z, Xinzhe G, Qiyue X (2018) The development of China's financial system: a global perspective. China Econ J 11(1):25-43

Pardo RP (2018) Europe's financial security and Chinese economic statecraft: the case of the Belt and Road Initiative. Asia Eur J 16(3):237-250

Peter A (2012) Bilateral trade, openness, and asset holdings. Open Econ Rev 23(4):713-740

Portes R, Rey H (2005) The determinants of cross-border equity flows. J Int Econ 65(2):269-296

Plummer MG (2006) ASEAN-EU economic relationship: integration and lessons for the ASEAN economic community. J Asian Econ 17(3):427-447

Pomfret R (2014) European crises and the Asian economies. J Asian Econ 31:71-81

Reilly J (2017) China's economic statecraft in Europe. Asia Eur J 15(2):173-185

Sautman B, Hairong Y (2007) Friends and interests: China's distinctive links with Africa. Afr Stud Rev 50(3):75-114

Von Hein M (2014) Germany and China: a special relationship? Deutsche Welle (DW). Available online at https://www.dw.com/en/germany-and-china-a-special-relationship/a-17759575 Accessed in January 2021 .

Zafar A (2007) The growing relationship between China and Sub-Saharan Africa: macroeconomic, trade, investment, and aid links. World Bank Res Observ 22(1):103-130

Publisher's note Springer Nature remains neutral with regard to jurisdictional claims in published maps and institutional affiliations.

\section{Authors and Affiliations}

\section{Alessandro Del Ponte ${ }^{1} \cdot$ Paolo Canofari ${ }^{2} \cdot$ Audrey De Dominicis $^{3}$}

Paolo Canofari

pcanofari@luiss.it

Audrey De Dominicis

adedominicis@unite.it

1 Global Asia Institute, National University of Singapore, 10 Lower Kent Ridge Rd 119076, Singapore

2 Department of Economics and Social Sciences, Marche Polytechnic University, Piazzale Martelli Raffaele, 8, 60121 Ancona, Italy

3 Faculty of Political Science, University of Teramo, Campus “Aurelio Saliceti” Via R. Balzarini, 64100 Teramo, Italy 